\title{
Diagnosing bovine parafilariosis: utility of the cytochrome $c$ oxidase subunit 1 gene and internal transcribed spacer region for PCR detection of Parafilaria bovicola in skin biopsies and serohemorrhagic exudates of cattle
}

\author{
Andreas W. Oehm ${ }^{1 *} \mathbb{C}$, Alexander Stoll' ${ }^{1}$ Cornelia Silaghi ${ }^{2,3}$, Annette Pfitzner-Friedrich',
} Gabriela Knubben-Schweizer ${ }^{1}$ and Christina Strube ${ }^{4}$

\begin{abstract}
Background: Parafilaria bovicola (Nematoda: Filariidae) causes cutaneous bleedings in bovine species. Flies serve as intermediate hosts. In recent years, reports on bovine parafilariosis have become more frequent, corroborating the necessity of reliable diagnostic interventions especially since no molecular or serological test has been available. We aimed to establish a polymerase chain reaction assay to detect DNA of P. bovicola in flies, skin biopsies and serohemorraghic exudates of bleeding spots.

Methods: PCRs targeting the cytochrome c oxidase subunit 1 (cox1) gene and the internal transcribed spacer region (ITS) of the ribosomal RNA gene cluster were evaluated for their diagnostic sensitivity as well as performance and specificity on biopsy and serohemorrhagic exudate samples from P. bovicola-infected cattle.

Results: Using serohemorrhagic exudates $(n=6)$, biopsies $(n=2)$ and flies $(n=1)$, the PCR targeting the cox1 gene resulted in a gel band of almost $700 \mathrm{bp}$. Cloning, sequencing, and removal of primer sequences yielded a 649-bp fragment of the P. bovicola cox 1 gene. The PCR targeting the ITS region showed a band of about $1100 \mathrm{bp}$. Cloning, sequencing, and removal of primer sequences resulted in a $1083 \mathrm{bp}$ stretch of the $P$. bovicola ITS region. Testing samples from presumably affected animals, the cox1-PCR resulted in bands with the expected size and they were all confirmed as P. bovicola by sequencing. In contrast, the ITS-PCR proved to be less sensitive and less specific and additionally amplified the ITS region of Musca domestica or buttercup DNA. When analysing for sensitivity, the cox 1PCR yielded visible bands up to $2 \mathrm{ng}$ of genomic DNA, whereas the ITS-PCR produced bands up to $3 \mathrm{ng}$. In a plasmid dilution series, the minimum number of target DNA copies was $10^{2}$ for the cox1-PCR and $10^{1}$ in the ITS-PCR.
\end{abstract}

Conclusions: The evaluated cox1-PCR enables reliable detection of P. bovicola DNA in skin biopsies and serohemorrhagic exudates. This PCR and, to a limited extent, the ITS-PCR, may help evaluate different therapeutic approaches. Furthermore, the cox1-PCR may be useful for epidemiological studies on the geographical distribution of P. bovicola. Further understanding of the epidemiology of this parasite will help develop and implement effective control strategies.

Keywords: Parafilaria bovicola, Cattle, Filarial nematode, Filarioidea, Microfilariae, PCR, cox1, ITS

*Correspondence: A.Oehm@med.vetmed.uni-muenchen.de

${ }^{1}$ Clinic for Ruminants with Ambulatory and Herd Health Services,

Ludwig-Maximilians-Universität Munich, Sonnenstrasse 16,

85764 Oberschleissheim, Germany

Full list of author information is available at the end of the article

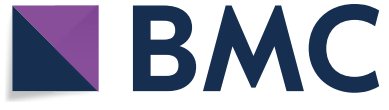

(c) The Author(s) 2019. This article is licensed under a Creative Commons Attribution 4.0 International License, which permits use, sharing, adaptation, distribution and reproduction in any medium or format, as long as you give appropriate credit to the original author(s) and the source, provide a link to the Creative Commons licence, and indicate if changes were made. The images or other third party material in this article are included in the article's Creative Commons licence, unless indicated otherwise in a credit line to the material. If material is not included in the article's Creative Commons licence and your intended use is not permitted by statutory regulation or exceeds the permitted use, you will need to obtain permission directly from the copyright holder. To view a copy of this licence, visit http://creativecommons.org/licenses/by/4.0/. The Creative Commons Public Domain Dedication waiver (http://creativecommons.org/publicdomain/zero/1.0/) applies to the data made available in this article, unless otherwise stated in a credit line to the data. 


\section{Background}

Parafilaria bovicola is a filarial nematode that causes signs of "cutaneous bleeding" in affected bovine species. In 1934, Tubangui [1] and de Jesus [2] were the first to give a profound parasitological description of this parasite. While the localization of the males is still mainly unknown, adult ovoviviparous females of P. bovicola live encapsulated in cutaneous and subcutaneous nodules [3] which they penetrate temporarily to oviposit through a fistulous tract to the cutaneous surface of their host. These lesions release serohemorrhagic exudates containing a mixture of eggs and microfilariae (first larval stage, L1). Microfilariae are ingested by intermediate hosts, such as Musca autumnalis in Europe, nourishing on the exudates [4]. In the intermediate host, ingested L1 develop into infective larvae (L3), for different periods (2-3 weeks) depending on environmental temperature [3]. L3 exit through the proboscis of the flies while these feed on secretions of mucous membranes of cattle and penetrate these. Subsequently, the migration of L3 larvae through subcutaneous tissues, development to adult stages and appearance of first bleeding spots require 7-9 months $[3,5,6]$.

Infection with $P$. bovicola is characterized by a seasonal occurrence of intermittent skin bleedings especially in the collar, scapular, withers and thoracic region $[3,4,6-9]$ and causes severe eosinophilic inflammation of the skin $[2,3,10,11]$, which may affect adjacent muscle tissues [7, 12]. Myiasis, expanded cutaneous ulcerations or necrosis, respectively, and secondary abscesses have equally been reported [2, 13, 14]. Parafilariainduced lesions have even been detected in sub-pleural, abdominal, mediastinal and perirenal tissues [15]. Lesions of this kind do often lead to condemnation of the entire carcass affected. Infested cattle show typical signs of infirmity [2].

Considerable economic losses have been demonstrated in meat production due to increased carcass trimming and reduced leather quality [12, 16-18]. Further studies have reported a marked decrease in milk yield and weight loss as a consequence of discomfort in infected cows as well $[8,13,18,19]$.

During the last few years there has been a remarkable increase of cases of parafilariosis in cattle with reports showing the presence of P. bovicola in Austria [20], Belgium [10], Germany [11], Italy [3] and The Netherlands [4]. Direct observation of bleeding spots and/or the presence of adult worms in carcasses or biopsies have so far been used to diagnose parafilariosis in cattle. Furthermore, microfilariae or larvated eggs can be detected in the serohemorrhagic exudate using microscopy.

However, the current detection methods for parafilariosis in cattle entail the risk of false diagnoses and thus are not satisfactory. So far, no molecular or serological test has been available to confirm diagnosis. Therefore, the aim of the present study was to evaluate a polymerase chain reaction assay (PCR) for detection of $P$. bovicola DNA in skin biopsies and serohemorrhagic exudates of bleeding spots to allow for fast and reliable diagnosis of clinical cases.

\section{Methods}

\section{Collection of $P$. bovicola adults}

Two cows displaying conspicuous bleeding spots were selected for the collection of skin biopsies or $P$. bovicola adults, respectively. The sites were clipped, cleaned using iodine soap and disinfected with $70 \%$ ethanol. A volume of $15.0 \mathrm{ml}$ of a local anaesthetic (lidocainhydrochloride) was injected subcutaneously around the site and after 10 min $70 \%$ ethanol was applied again.

An almost $2.0 \mathrm{~cm}$ long, white worm was observed in the center of the swollen skin site, trying to leave the skin. The worm was gently removed manually and transferred to $70 \%$ ethanol in a $10 \mathrm{ml}$ Falcon tube.

Another worm was collected as described above during preparation for a biopsy of a bleeding spot in a dairy cow. Parafilaria bovicola abruptly pervaded the skin when the site was manipulated and remained sticking on the skin surface. The worm was collected manually and stored in $70 \%$ ethanol at $4{ }^{\circ} \mathrm{C}$. Both nematodes were examined morphologically and identified as female specimens of $P$. bovicola [21].

\section{Collection of serohemorrhagic exudates, skin biopsies, blood and flies}

Fresh (hereafter referred to as "liquid exudate") or dry samples (hereafter referred to as "dried exudate") of the bleeding spots of presumably affected animals as well as of those animals, from which the two adult specimens of P. bovicola were isolated, were collected. These samples were transferred to $70 \%$ ethanol and kept at $-20^{\circ} \mathrm{C}$.

To obtain biopsies, conspicuous skin sites were prepared as described above and an individually wrapped, disposable and sterile biopsy punch of $8 \mathrm{~mm}$ in diameter (Jørgen Kruuse A/S, Langeskov, Denmark) was used to cut out a cylindrical piece of skin. Biopsies were conserved in $70 \%$ ethanol and frozen at $-20{ }^{\circ} \mathrm{C}$.

As negative controls, EDTA blood and skin biopsies from clinically sound cows at the Clinic for Ruminants and at the Livestock Center of the Ludwig-MaximiliansUniversität, Munich, Germany, were collected. This was in compliance with animal welfare standards. Additionally, flies (Musca sp.) were caught at presumably affected farms as potential sources of contaminating DNA in bleeding spots as well as potential $P$. bovicola intermediate host. 


\section{DNA extraction and PCR of adult P. bovicola}

Genomic DNA was isolated from an approximately 10 mm piece of the adult worm using the NucleoSpin ${ }^{\circledR}$ Tissue Kit (Macherey-Nagel, Düren, Germany). Subsequent PCRs targeted the cytochrome $c$ oxidase subunit 1 (cox1) gene by using the primers COIintf and COIintR [22] as well as the internal transcribed spacer region (ITS1 region, 5.8S rDNA and ITS2 region with flanking $18 S$ and $28 S$ rDNA sequences) using the primers NC5 and NC2 [23]. The reaction set-up for both PCRs comprised 25 $\mu \mathrm{l}$, containing $0.5 \mu \mathrm{l}$ DreamTaq DNA Polymerase (5 U/ $\mu \mathrm{l})$ (Thermo Fisher Scientific, Schwerte, Germany), $2.5 \mu \mathrm{l}$ $10 \times$ DreamTaq buffer, 0,5 $\mu \mathrm{l}$ dNTP mix (10 mM each), 1 $\mu \mathrm{l}$ of each forward and reverse primer $(10 \mu \mathrm{M}$ each $)$ and $1 \mu \mathrm{l}$ DNA template. Thermocycling conditions targeting the cox 1 gene were as follows: initial denaturation at 95 ${ }^{\circ} \mathrm{C}$ for $3 \mathrm{~min}, 30$ cycles of $95{ }^{\circ} \mathrm{C}$ for $30 \mathrm{~s}, 55^{\circ} \mathrm{C}$ for $30 \mathrm{~s}$, $72{ }^{\circ} \mathrm{C}$ for $30 \mathrm{~s}$ and a final elongation step at $72{ }^{\circ} \mathrm{C}$ for 10 min. Thermocycling conditions targeting the ITS-region were: initial denaturation at $95{ }^{\circ} \mathrm{C}$ for $3 \mathrm{~min}, 30$ cycles of $95{ }^{\circ} \mathrm{C}$ for $45 \mathrm{~s}, 50{ }^{\circ} \mathrm{C}$ for $45 \mathrm{~s}, 72{ }^{\circ} \mathrm{C}$ for $90 \mathrm{~s}$ and a final elongation step at $72{ }^{\circ} \mathrm{C}$ for $10 \mathrm{~min}$. The PCR products were visualized on a $1 \%$ agarose gel.

Afterwards, the amplicons were inserted into the $\mathrm{pCR}^{\mathrm{TM}} 4-\mathrm{TOPO}^{\circledR}$ vector and cloned into One Shot ${ }^{\circledR}$ TOP10 chemically competent E. coli using the TOPO $^{\circledR}$ TA Cloning ${ }^{\circledR}$ Kit for Sequencing (Invitrogen, Schwerte, Germany). Plasmid DNA was obtained using the NucleoSpin ${ }^{\circledR}$ Plasmid Kit (Macherey-Nagel) following the manufacturer's recommendations. Subsequently, the inserts were custom-sequenced (Seqlab Sequence Laboratories, Göttingen, Germany) and analysed by BLASTn against publicly available nucleotide sequences. After removal of primer sequences, the newly generated sequences were deposited in the GenBank database under the accession numbers MG983750 and MG983751.

\section{Sensitivity of the cox 1- and ITS-PCR}

To test the analytic sensitivity of the cox1- and ITS-PCR, dilution series of adult worm genomic DNA and plasmids inserting the cox1- and ITS amplification products (see above) were generated. To prepare dilutions, the yield of isolated genomic DNA and plasmid DNA was determined by measuring the absorbance at $260 \mathrm{~nm}$

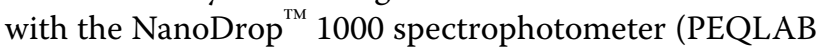
Biotechnologie $\mathrm{GmbH}$, Erlangen, Germany). For testing genomic DNA dilutions as template, PCRs were performed as described above using the following amounts of DNA template: $100 \mathrm{ng}, 50 \mathrm{ng}, 20 \mathrm{ng}, 10 \mathrm{ng}$ to $1 \mathrm{ng}$ (1000 pg), $100 \mathrm{pg}, 50 \mathrm{pg}, 10 \mathrm{pg}$ to $1 \mathrm{pg}$. For testing plasmid DNA, 10-fold serial dilutions ranging from $10^{9}$ to $10^{0}$ target copies per PCR reaction were prepared. Each $10 \mu \mathrm{l}$ amplification product was run on a $1 \%$ agarose gel stained with GelRed ${ }^{\circledR}$ (Biotium Inc., Fremont, CA, USA) and visualized under UV light.

\section{DNA extraction and PCR of serohemorrhagic exudates, skin biopsies, blood and flies}

For an initial screening whether the $\operatorname{cox} 1$ - and ITS-PCRs are suitable to detect $P$. bovicola DNA in samples of presumably affected bovines, genomic DNA was isolated with the NucleoSpin ${ }^{\circledR}$ Tissue Kit from $100 \mu \mathrm{l}$ and $200 \mu \mathrm{l}$ native liquid exudate of two cows each. Additionally, liquid exudate fixed in $70 \%$ ethanol from one of the cows was subjected to DNA isolation. PCRs targeting the cox 1 gene and ITS region were conducted as described above, with the exception that $2 \mu \mathrm{l}$ genomic DNA was used as template. Genomic DNA from the adult P. bovicola worm was used as a positive control. From each PCR product, $10 \mu \mathrm{l}$ were loaded on a $1 \%$ agarose gel to visualize the amplicons.

For final experiments, genomic DNA was isolated from $100 \mu \mathrm{l}$ liquid exudate (native or fixed with ethanol), 100 $\mu \mathrm{g}$ dried exudate, 20-30 $\mu \mathrm{g}$ skin biopsy and one $\mathrm{Musca}$ sp. fly caught at an affected farm. Again, $2 \mu \mathrm{l}$ were used as PCR template and $10 \mu \mathrm{l}$ PCR product was loaded on a $1 \%$ agarose gel to visualize the amplicons. Selected (ITS-PCR) or all (cox1-PCR) bands at approximately the right size were excised and custom-sequenced (Seqlab Sequence Laboratories, Göttingen, Germany). Obtained sequences were compared with the sequences generated from the adult $P$. bovicola specimen and by BLASTn against public databases.

\section{Results}

\section{Amplification of adult $P$. bovicola DNA}

The PCR targeting the cox 1 gene resulted in a gel band of almost $700 \mathrm{bp}$ in size. Cloning and sequencing revealed an amplification product of $689 \mathrm{bp}$ and after removal of the primers, sequences a 649-bp fragment of the cox 1 gene of $P$. bovicola was obtained. BLASTn sequence comparison resulted in the cox1 gene of Onchocerca gibsoni as a top hit (GenBank: AJ271616; identity: 88\%; query cover, QC: 98\%; e-value: 0.0), followed by Spirocerca lupi (GenBank: KC305876; identity: 87\%; QC: 100\%; e-value: 0.0 ) and Dirofilaria repens (GenBank: KR998259; identity: 87\%; QC: 99\%; e-value: 0.0).

The ITS-PCR showed a band of about $1100 \mathrm{bp}$ in size. Cloning and sequencing resulted in an amplification product of $1129 \mathrm{bp}$ and after removal of the primer sequences in a 1083-bp fragment. The closest match via BLASTn search was the ITS region of Onchocerca fasciata (GenBank: JQ316671, identity: 77\%; QC: 42\%; e-value: 1e-80), followed by Brugia pahangani (GenBank: EU373654; identity: 75\%; QC: 43\%; e-value: 3e-75) 
and Parabronema skrjabini (GenBank: EU375510; identity: 76\%; QC: 41\%; e-value: 3e-75).

\section{Sensitivity of the cox1- and ITS-PCR}

Testing the analytic sensitivity of the PCRs revealed that the cox1-PCR produced visible bands with as little as 2 ng of genomic DNA template (Fig. 1), while the ITS-PCR produced bands with as little as $3 \mathrm{ng}$ of genomic DNA template. When using plasmid dilution series to determine the required minimum number of target DNA copies, cox1-PCR resulted in bands with a minimum of $10^{2}$ target copies, while the minimum copy number was $10^{1}$ in the ITS-PCR (Fig. 2).

\section{PCR of serohemorrhagic exudates, skin biopsies, blood and flies}

A total of six samples of serohemorrhagic exudate, two biopsies and one fly were included in this analysis. Initial screening cox1- and ITS-PCRs using different amounts of native and fixed liquid exudate for DNA isolation revealed bands at the expected size of about $700 \mathrm{bp}$ (cox1-PCR, Fig. 3) and 1100 bp (ITS-PCR, Fig. 4), respectively, for all PCR reactions. When comparing band intensity, the amount of $100 \mu \mathrm{l}$ liquid exudate used for DNA isolation was not inferior to $200 \mu$ liquid exudate. However, the bands originating from liquid exudate samples fixed (and thus diluted) in 70\% ethanol were rather faint compared with the native exudate samples.
When testing all available samples from presumably affected animals, cox1-PCR resulted in a band at the expected size for each sample. Samples from control animals as well as the Musca sp. fly from a presumably affected farm remained negative (Fig. 5). In contrast, ITS-PCR did not reveal a band at the expected size or no bands at all in two samples (Lanes 9, 11, Fig. 6). Again, samples from control animals remained negative, but amplification of the Musca sp. fly DNA resulted in a strong band at the expected size (Fig. 6).

\section{Sequencing of amplification products from serohemorrhagic exudates, skin biopsies and flies}

Sanger sequencing was performed with all cox1-PCR amplification products (or excised gel bands, respectively) of the presumably affected animals (Lanes 4-12 in Fig. 5) and with the prominent bands at $c .1100 \mathrm{bp}$ from Lanes 4, 12 and 14 (Musca sp. fly) as well as the prominent short band at $c .700$ bp (Lane 9 in Fig. 6) from the ITS-PCR products. In sequences alignment search, all obtained sequences perfectly matched the $P$. bovicola cox 1 sequence generated from the adult worm (see above, GenBank: MG983751) and the bands at the expected size of the presumably affected cows (Lanes 4, 12) matched the P. bovicola ITS sequence generated from the adult worm (see above, GenBank: MG983750). However, the band of the Musca sp. fly (Lane 15) matched a Musca domestica ITS sequence (GenBank: Z28417) and the short 700 bp band (Lane 9) of a presumably affected

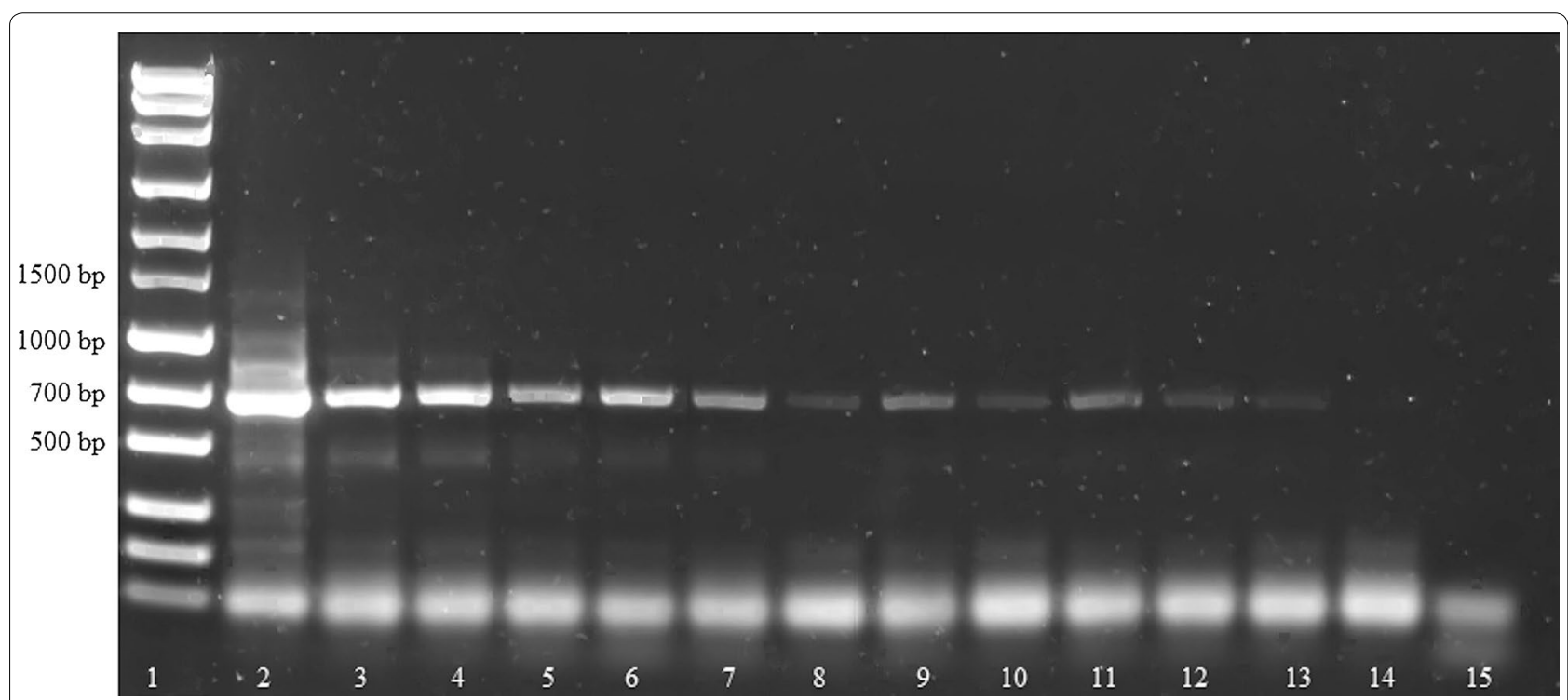

Fig. 1 Sensitivity of the cox1-PCR using genomic DNA dilutions as template. Lane 1: marker (MassRuler ${ }^{\circledR}$ Express Forward DNA Ladder Mix, Thermo Fisher Scientific); Lane 2: 1000 pg genomic DNA; Lane 3: 100 pg genomic DNA; Lane 4: 50 pg genomic DNA; Lane 5: 10 pg genomic DNA; Lane 6: 9 pg genomic DNA; Lane 7: 8 pg genomic DNA; Lane 8: 7 pg genomic DNA; Lane 9: 6 pg genomic DNA; Lane 10: 5 pg genomic DNA; Lane 11: 4 pg genomic DNA; Lane 12: 3 pg genomic DNA; Lane 13: 2 pg genomic DNA; Lane 14: 1 pg genomic DNA; Lane 15: no-template control 


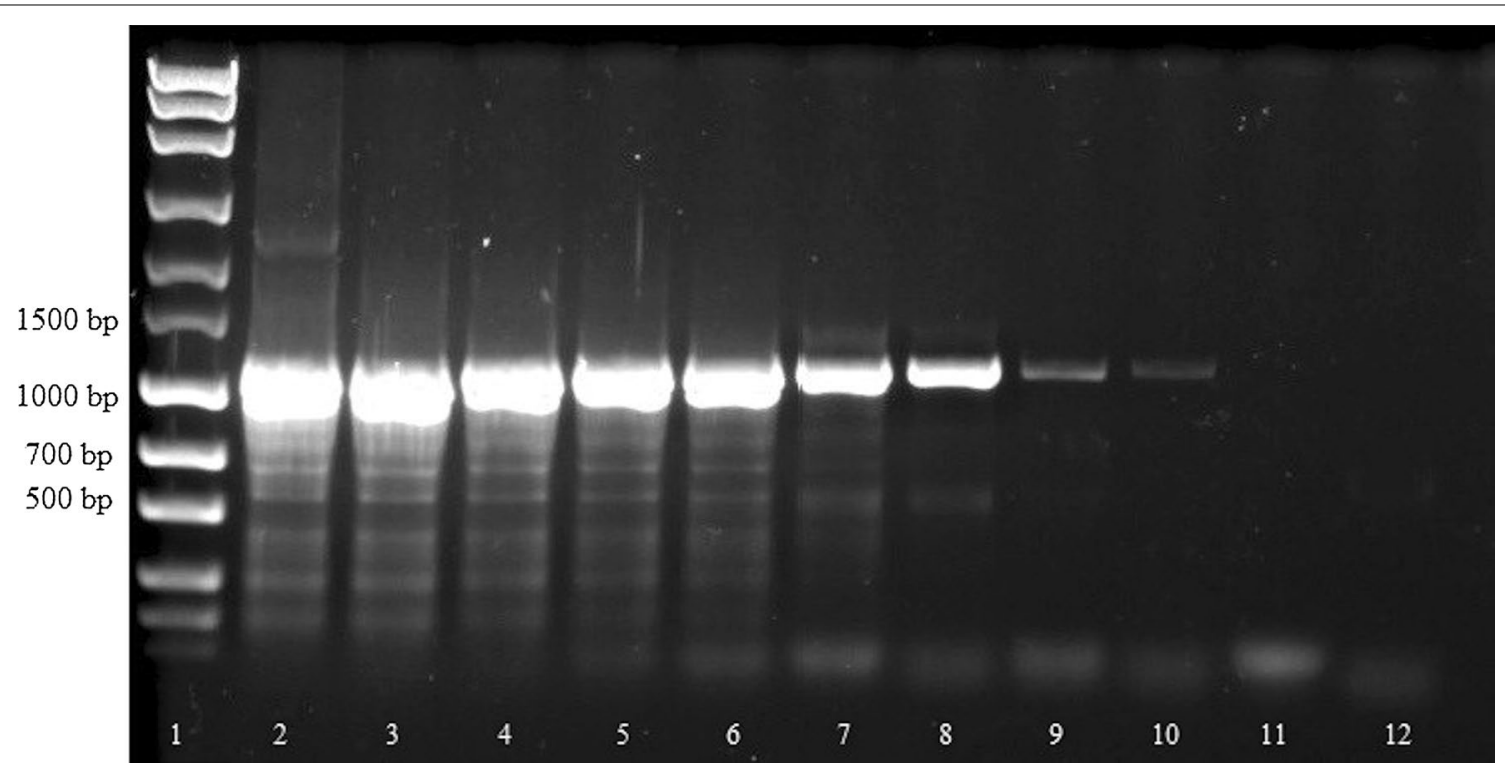

Fig. 2 Sensitivity of the ITS-PCR using serial plasmid dilutions as template. Lane 1: marker (MassRuler ${ }^{\circledR}$ Express Forward DNA Ladder Mix, Thermo Fisher Scientific); Lane 2: $10^{9}$ target copies; Lane 3: $10^{8}$ target copies; Lane 4: $10^{7}$ target copies; Lane 5: $10^{6}$ target copies; Lane 6: $10^{5}$ target copies;

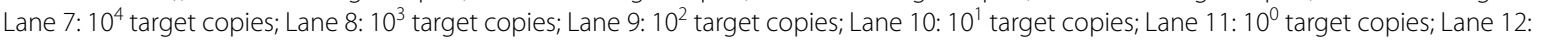
no-template control

cow was identified as ITS region of a buttercup species (Ranunculus subcorymbosus, GenBank: FM242810).

\section{Discussion}

Cutaneous bleeding in cattle always represents an exceptional situation in daily veterinary practice work. In recent years, reports on the occurrence of cases of bleeding cattle have become more abundant [3, 4, 24]. It is unclear whether this refers to an enhanced interest in bleeding cattle after the emergence of bovine neonatal pancytopenia in 2006 and 2007 [25-27] or to an actual increase in the prevalence of $P$. bovicola in cattle. Regarding the latter, Brooks et al. [28] have elucidated that the emergence of "new diseases" can be traced back to either an introduction into previously non-endemic areas or to an environmental change in regions they spread to. Climate change has been demonstrated to have pronounce effects on the epidemiology, spatial spread and seasonal dynamics of parasite populations $[29,30]$. Parasite stages that are dependent on intermediate hosts are distinctively sensitive to climatic alterations influencing themselves as well as the abundance, resilience and reproduction of their intermediate hosts [31]. Therefore, reduced temperature limitations may enable new pathogen species to establish in hitherto free areas [28, 31-33].

To date, diagnosis of bovine parafilariosis has been restricted to the presence and interpretation of clinical signs, which, however, are not a confirmation or detection

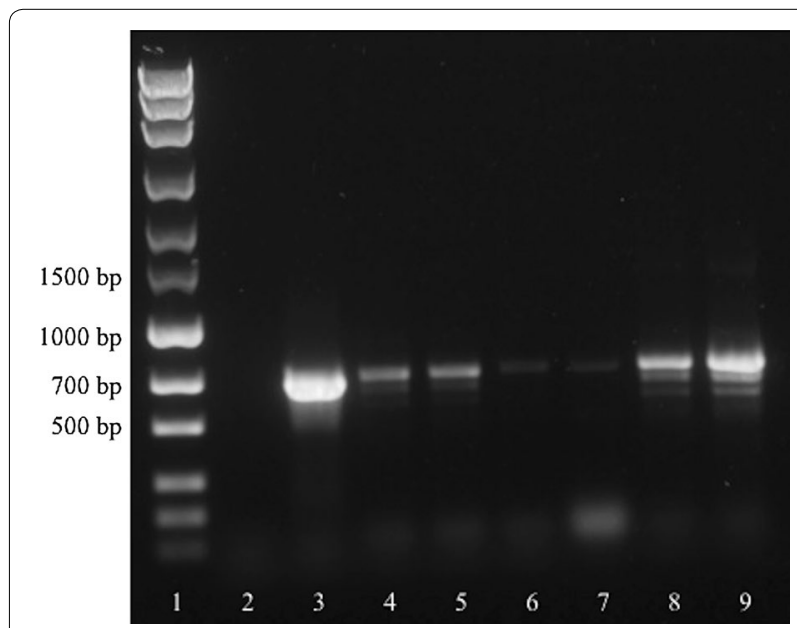

Fig. 3 Initial screening amplification of liquid exudate samples using cox1-PCR. Lane 1: marker (MassRuler ${ }^{\mathrm{TM}}$ Express Forward DNA Ladder Mix, Thermo Fisher Scientific); Lane 2: no-template control; Lane 3: positive control; Lane 4: $100 \mu \mathrm{l}$ native liquid exudate (cow 1); Lane 5: $200 \mu$ l native liquid exudate (cow 1); Lane 6: $100 \mu$ l liquid exudate fixed in 70\% ethanol (cow 2); Lane 7: $200 \mu$ l liquid exudate fixed in $70 \%$ ethanol (cow 2); Lane 8: $100 \mu$ l native liquid exudate (cow 2); Lane 9: $200 \mu$ l native liquid exudate (cow 2)

of adult worms, eggs or microfilariae, from freshly active bleeding spots shortly after start of the bleeding [34]. Isolation of adult specimens or searching for eggs and microfilariae in serohemorrhagic exudates is fairly unreliable $[9,19,35]$. According to our own experience, adult 


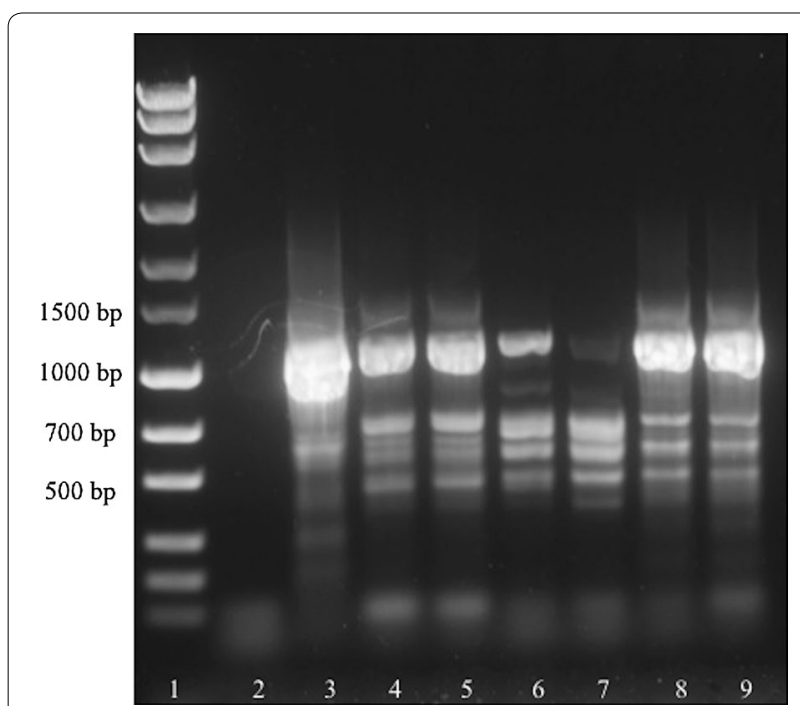

Fig. 4 Initial screening amplification of liquid exudate samples using ITS-PCR. Lane 1: marker (MassRuler ${ }^{\circledR}$ Express Forward DNA Ladder Mix, Thermo Fisher Scientific); Lane 2: no-template control; Lane 3: positive control; Lane 4: $100 \mu$ native liquid exudate (cow 1); Lane 5: $200 \mu$ l native liquid exudate (cow 1); Lane 6: $100 \mu$ l liquid exudate fixed in 70\% ethanol (cow 2); Lane 7: $200 \mu$ l liquid exudate fixed in 70\% ethanol (cow 2); Lane 8: $100 \mu \mathrm{l}$ native liquid exudate (cow 2); Lane 9: $200 \mu \mathrm{l}$ native liquid exudate (cow 2)

P. bovicola are very elusive and hence their collection is challenging and is successful only in very few cases. This is further corroborated by Borgsteede et al. [4], who reported that no eggs or microfilariae were detected in the exudate of a breeding bull, even though female worms containing large numbers of eggs with microfilariae were detected during necropsy. Sundquist et al. [36, 37] developed an ELISA based on native exoantigen of the parasite, which allowed for sensitive and specific detection of antibodies against $P$. bovicola but required a continuous supply and thus continuous availability of worms for coating of the ELISA plates. This proved to be impractical and the method could not be widely established. Nevertheless, serological assays detecting antibodies against exoantigens of adult worms may have the limitation of a lag-phase, in which egg-laying adult worms may be present but antibodies have not yet been developed.

Thus, the aim of the present study was to evaluate a PCR assay for detection of $P$. bovicola DNA in samples of infected cattle to provide an easy and reliable diagnostic approach for bovine parafilariosis. Casiraghi et al. [22] have shown the phylogenetic relationships between filarial nematodes based on mitochondrial DNA, i.e. cox1 gene sequences. Mitochondrial DNA is phylogenetically conserved within specimens of a taxon and the cox 1 gene has thus been used in a range of taxonomic studies to disentangle phylogenetic relationships among species [38-42]. Besides mitochondrial DNA, the ribosomal ITS region is an excellent target to discriminate nematodes (reviewed in Blouin [43]) and has been frequently used for filarial species delineation and identification [4, 43-46]. Therefore, the cox 1 gene as well as the ITS region were chosen as targets in our PCR approach and compared regarding their suitability as diagnostic tools

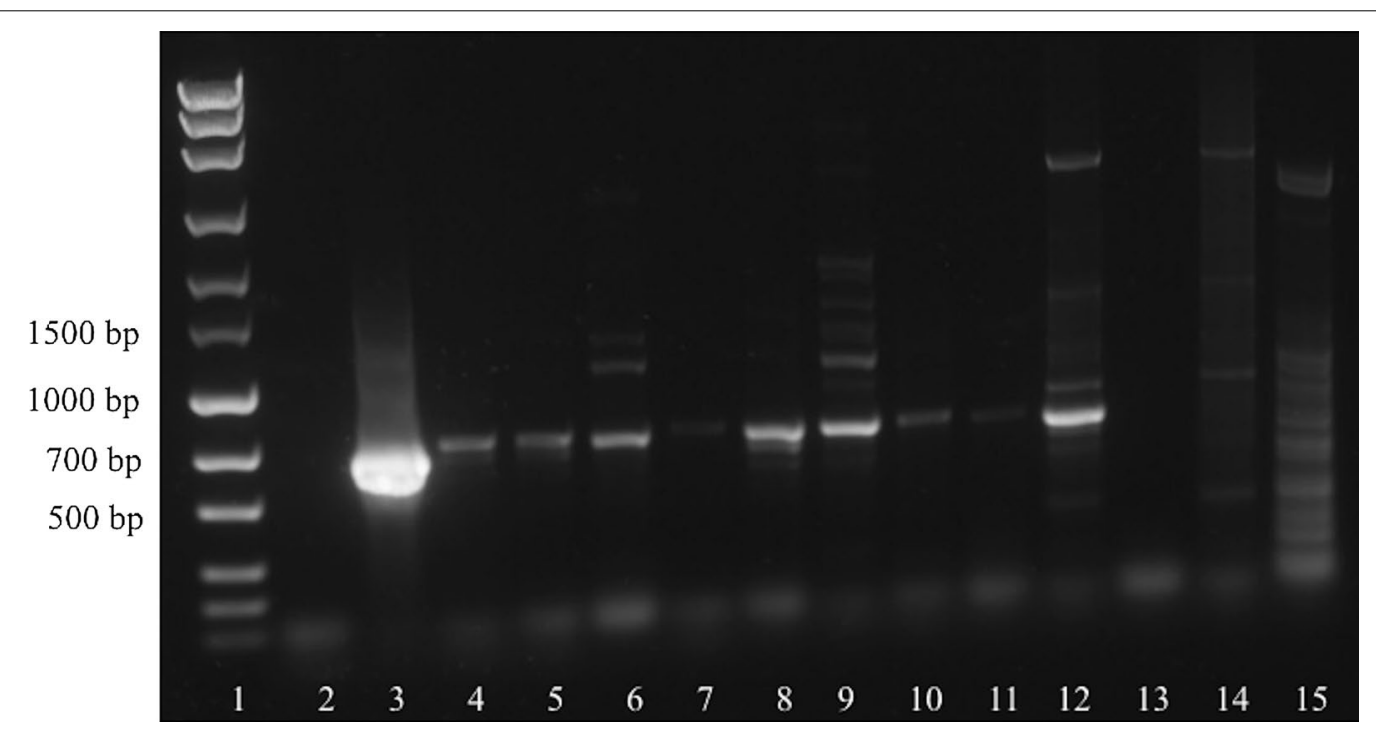

Fig. 5 Detection of P. bovicola in samples from presumably affected (Lanes 4-12) and control animals (Lanes 13-14) and a Musca sp. fly using cox1-PCR. Lane 1: marker (MassRuler ${ }^{\circledR}$ Express Forward DNA Ladder Mix, Thermo Fisher Scientific); Lane 2: no-template control; Lane 3: positive control; Lane 4: native liquid exudate (cow 1); Lane 5: native liquid exudate (cow 3); Lane 6: native liquid exudate (cow 4); Lane 7: liquid exudate fixed in 70\% ethanol (cow 2); Lane 8: native liquid exudate (cow 2); Lane 9: native liquid exudate (cow 5); Lane 10: dry exudate (cow 2); Lane 11: dry exudate (cow 6); Lane 12: skin biopsy fixed in 70\% ethanol (cow 7); Lane 13: EDTA blood (control cow 1); Lane 14: skin biopsy (control cow 2); Lane 15: Musca fly 


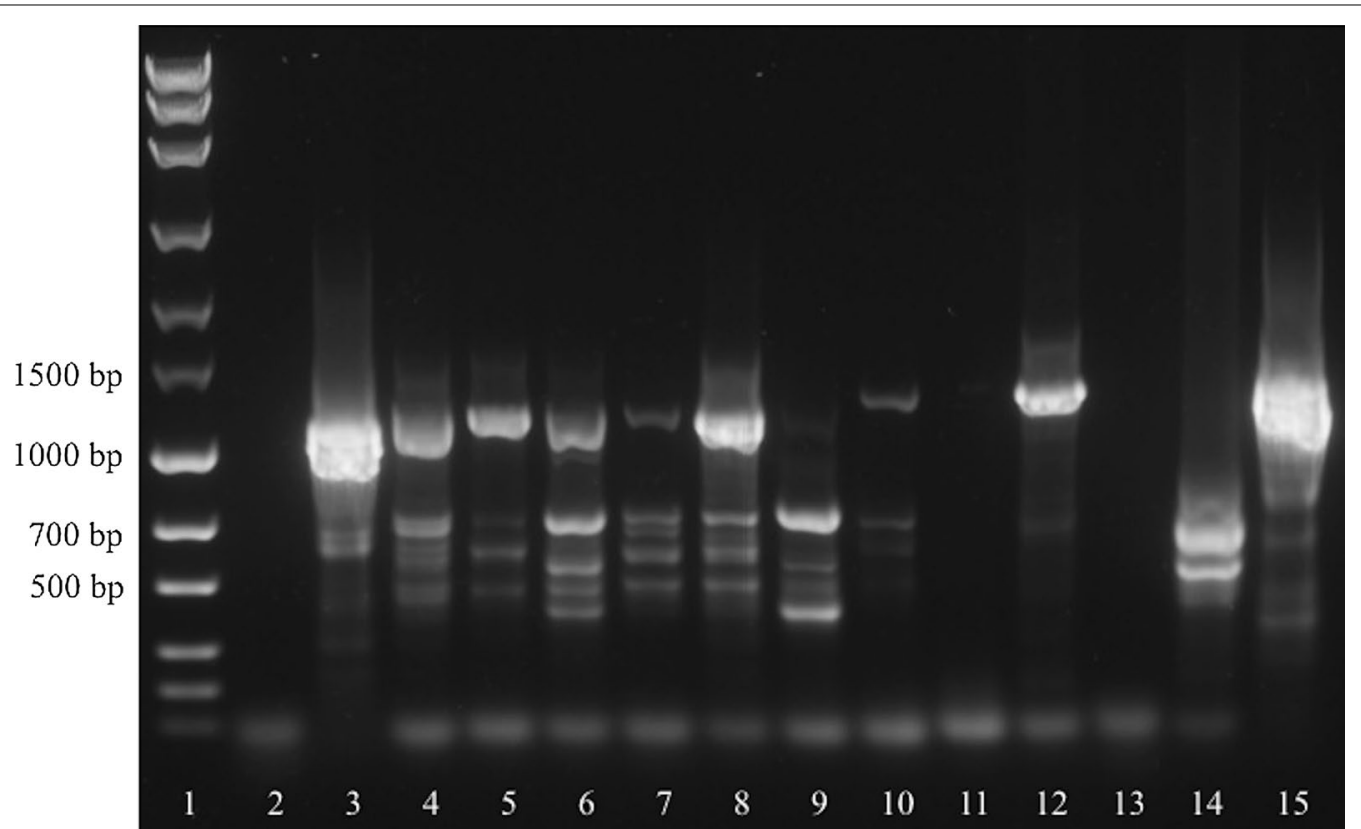

Fig. 6 Detection of P. bovicola in samples from presumably affected (Lanes 4-12) and control animals (Lanes 13-14) and a Musca sp. fly using ITS-PCR. Lane 1: marker (MassRuler ${ }^{\circledR}$ Express Forward DNA Ladder Mix, Thermo Fisher Scientific); Lane 2: no-template control; Lane 3: positive control; Lane 4: native liquid exudate (cow 1); Lane 5: native liquid exudate (cow 3); Lane 6: native liquid exudate (cow 4); Lane 7: liquid exudate fixed in 70\% ethanol (cow 2); Lane 8: native liquid exudate (cow 2); Lane 9: native liquid exudate (cow 5); Lane 10: dry exudate (cow 2); Lane 11: dry exudate (cow 6); Lane 12: skin biopsy fixed in 70\% ethanol (cow 7); Lane 13: EDTA blood (control cow 1); Lane 14: skin biopsy (control cow 2); Lane 15: Musca sp. fly

for bovine parafilarosis. Both cox1- and ITS-PCR amplified genomic DNA isolated from an adult worm, enabled us to provide the first $P$. bovicola sequences in public databases. Since $P$. bovicola is classified within the superfamily Filarioidea, it was at first glance not surprising that for both, the cox 1 and ITS sequences, an Onchocerca species was the top hit in sequence identity search. However, the genus Onchocerca belongs to the family Onchocercidae, while the genus Parafilaria is a member of the family Filariidae. For the Filariidae, a few $\operatorname{cox} 1$ sequences are publicly available for species of the genus Filaria. Interestingly, respective top matches from this family (Filaria sp., KJ612514; and Filaria martis, KU761590) showed lower sequence identity (KJ612514: identity: 85\%; QC: 97\%; e-value: 0.0; KU761590: identity: 82\%; QC: $99 \%$; e-value: 0.0 ) with the $\operatorname{cox} 1$ sequence for $P$. bovicola than various members of the family Onchocercidae or even e.g. S. lupi of the superfamily Spiruroidea. Overall, no member of the family Filariidae was amongst the available top 100 BLAST hit descriptions.

Testing the analytical sensitivity of the cox1- and ITSPCR showed that both PCRs are very sensitive using plasmids inserting the target sequence as a simple template. Here, the PCRs produced visible bands with 100 and 10 target copies, respectively. Similarly, when using genomic $P$. bovicola DNA as a more complex template, both PCRs performed well with a detection limit of 2-3 pg template DNA. Such successful amplification allowed us to transfer the PCR protocols to diagnostic material from presumably $P$. bovicola infected cattle, a quite complex template, because parasite DNA is mixed (to a more or less large degree) with host DNA. As diagnostic material collection from cutaneous bleedings is limited in its amount, we compared PCR efficiency after DNA extraction from $100 \mu \mathrm{l} v s 200 \mu \mathrm{l}$ liquid exudate. Interestingly, gel band intensity was mostly unaffected by the amount used for DNA extraction, but fixation of the exudate in $70 \%$ ethanol significantly reduced PCR efficiency. Since the reduction in band intensity was disproportionately high, the reason is most likely less efficient DNA isolation due to ethanol precipitation of DNA rather than a dilution effect. Based on these findings, a sample volume of $100 \mu \mathrm{l}$ serohemorrhagic exudate is sufficient for PCR diagnostics, but samples should not be conserved with ethanol but rather kept cool or frozen until analysis.

When analyzing all available samples of presumably $P$. bovicola-affected cows, cox1-PCR reliably detected all of them as positive. Again, the ethanol-fixed liquid exudate sample resulted in a faint band only, whereas the utilized $20 \mu \mathrm{g}$ ethanol-fixed skin biopsy showed a prominent signal, indicating that this biopsy contained more eggs or microfilariae than the exudate, which originated from a different cow. Noteworthy, amplification efficacy and thus band intensity of dried exudate was inferior to liquid exudate. Consequently, liquid serohemorrhagic exudate 
or skin biopsies should be collected for PCR diagnosis whenever possible.

Results of the ITS-PCR were inferior compared to cox1$\mathrm{PCR}$, as no amplification signal was observed with one of the two dried exudate samples and, furthermore, one liquid exudate sample resulted in a prominent band below the expected amplicon size, whereas the band at the correct size could only be suspected (cf. Lane 9, Fig. 6). Sequencing showed that the prominent band represented the ITS sequence of a buttercup. This can be explained by adhering or trapped buttercup seeds or small leaf particles in the liquid exudate when cows lay down on the pasture to ruminate. Moreover, ITS-PCR resulted in a very strong band at the expected $P$. bovicola amplicon size when amplifying DNA isolated from a Musca sp. fly from an affected farm. Sequencing revealed this amplification product as an ITS sequence of the housefly Musca domestica. This result is a major shortcoming of the ITS-PCR, as flies may deposit their eggs in the wounds or exudate, leading to false positive results in P. bovicola diagnosis by ITS-PCR. Furthermore, this undesired amplicon of Musca sp. DNA at the expected P. bovicola amplicon size, excludes the ITS-PCR from epidemiological studies on the prevalence of infected flies in affected farms.

From a therapeutic point of view, our cox1-PCR and, to a limited extent, the ITS-PCR, may serve as a potential control for the effects of several therapeutic approaches for parafilariosis in cattle. In this context, Torgerson et al. [17] reported that the use of anthelmintic drugs is not sufficiently efficient against $P$. bovicola. The cox1-PCR method described in this paper will facilitate the evaluation of the outcomes of implementing different anthelmintic compounds in infected bovines and their effects on different developmental stages of $P$. bovicola and therefore help diagnosing and monitoring with this emerging parasite. Furthermore, the presented PCR assay provides a non-invasive tool to further investigate the biology and presence of this emerging parasite, since it has not been yet understood how long and to what extent are larval stages persistent in flies. This is of crucial importance since intermediate hosts are a central element in the epidemiology of $P$. bovicola and Nevill et al. [44] pointed out that face flies of the genus Musca are extremely competent in transmission dynamics. Van Dijk et al. [29] illustrated that helminths are able to rapidly adapt to new environmental conditions, which can be attributed to their relatively short generation times. As a consequence of milder climatic conditions, helminth evolution may be accelerated to an extent mammal host are not able to keep up with. This puts further emphasis on the necessity of improved diagnostic approaches for surveillance of parasite population dynamics, evaluation of parasite burdens in livestock and therapeutic efficiency of anthelmintics [29]. Finally, the evaluated cox1-PCR represents a tool for epidemiological studies to monitor the geographical expansion of $P$. bovicola in previously non-endemic regions by using bovine samples or intermediate host flies. Further understanding of the epidemiology of this emerging parasite will help develop and implement effective control strategies to minimise the impact on productivity and welfare of cattle.

\section{Conclusions}

The cox1-PCR presented here enables reliable detection of $P$. bovicola DNA in presumably affected animals. From a therapeutic point of view, cox1-PCR and, to a limited extent, the ITS-PCR, may serve as potential controls for the effects of several therapeutic approaches for parafilariosis in cattle. Finally, the evaluated cox1-PCR represents a tool for epidemiological studies on the geographical distribution of $P$. bovicola by using bovine samples or intermediate host flies. Further understanding of the epidemiology of this emerging parasite will help develop and implement effective control strategies to minimise the impact on productivity and welfare of cattle.

\section{Abbreviations \\ BLAST: Basic Local Alignment Search Tool; bp: base pair(s); cox1: cytochrome c oxidase subunit 1 gene; DNA: deoxyribonucleic acid; ITS: internal tran- \\ scribed spacer region; PBS: phosphate-buffered saline; PCR: polymerase chain reaction.}

\section{Acknowledgements \\ The authors wish to cordially express their gratitude to Jan Chirico for gener- ously providing documents and materials. We furthermore thank Sandra Kirsch, Claudia Thiel, Andrea Mihalkov and Ulla Küttler for excellent technical assistance.}

\section{Authors' contributions}

AOE, AS, CSI and CST performed experimental work. CSI performed morphological species identification and revised the manuscript. AOE, AS and CST analyzed the data and wrote the manuscript. GKS and APF supervised the experiment, participated in the design of the study and revised the manuscript. All authors read and approved the final manuscript.

\section{Funding}

Not applicable.

\section{Availability of data and materials}

Data supporting the conclusions of this article are included within the article. The newly generated sequences were deposited in the GenBank database under the accession numbers MG983750 and MG983751. The datasets used and/or analysed during the present study are available from the corresponding author upon reasonable request.

\section{Ethics approval and consent to participate}

Not applicable.

\section{Consent for publication}

Not applicable.

Competing interests

The authors declare that they have no competing interests.

\section{Author details}

${ }^{1}$ Clinic for Ruminants with Ambulatory and Herd Health Services, LudwigMaximilians-Universität Munich, Sonnenstrasse 16, 85764 Oberschleissheim, 
Germany. ${ }^{2}$ Institute for Comparative Tropical Medicine and Parasitology, Ludwig-Maximilians-Universität Munich, Leopoldstrasse 5, 80802 München, Germany. ${ }^{3}$ Institute of Infectology (IMED), Friedrich-Loeffler-Institute, Südufer 10, 17493 Greifswald-Insel Riems, Germany. ${ }^{4}$ Institute for Parasitology, Centre for Infection Medicine, University of Veterinary Medicine Hannover, Buenteweg 17, 30559 Hanover, Germany.

Received: 17 August 2019 Accepted: 5 December 2019

Published online: 11 December 2019

\section{References}

1. Tubangui MA. Nematodes in the collection of the Philippine Bureau of Science, II: Filarioidea. Philipp J Sci. 1934;55:115-22.

2. De Jesus Z. Haemorrhagic filariasis in cattle caused by a new species of Parafilaria. Philipp J Sci. 1934;55:125-30.

3. Galuppi R, Militerno G, Bassi P, Nanni A, Testoni S, Tampieri M, et al. Evidence for bovine parafilariosis in Italy: first isolation of Parafilaria bovicola (Tubangui, 1934) from autochthonous cattle. Vet Parasitol. 2012;184:88-91.

4. Borgsteede FH, van Wuijckhuise L, Peutz J, Roumen T, Kock P. Import of Parafilaria bovicola in the Netherlands. Vet Parasitol. 2009;161:146-9.

5. Nevill E, Viljoen J. The longevity of adult Parafilaria bovicola and the persistence of their associated carcass lesions in cattle in South Africa. Onderstepoort J Vet Res. 1984;51:115-8.

6. Viljoen J, Boomker J. Studies on Parafilaria bovicola Tubangui, 1934, 2. Chemotherapy and pathology. Onderstepoort J Vet Res. 1977;44:107-12.

7. Viljoen J, Coetzer J. Studies on Parafilaria bovicola Tubangui, 1934 III. Pathological changes in infested calves. Onderstepoort J Vet Res. 1982;49:29-40.

8. Losson B, Saegerman C. First isolation of Parafilaria bovicola from clinically affected cattle in Belgium. Vet Rec. 2009;164:623-6.

9. Groeneveld $\mathrm{H}$, Carmichael I. Evaluation of the efficacy of anthelmintics against parafilariosis in cattle. Onderstepoort J Vet Res. 1990;57:103-8.

10. Caron Y, Groignet S, Losson BJ, Saegerman C. Three cases of Parafilaria bovicola infection in Belgium, and a few recent epidemiological observations on this emergent disease. Vet Rec. 2013;172:129.

11. Hamel D, Axt H, Pfister K. First report on Parafilaria bovicola (Nematoda: Filaroidea) in Germany. Res Vet Sci. 2010;89:209-11.

12. Bech-Nielsen S, Sjogren U, Lundquist H. Parafilaria bovicola (Tubangui 1934) in cattle: epizootiology-disease occurrence. Am J Vet Res. 1982;43:945-7.

13. Merker MK. Treatment with ivermectin of cattle naturally infested with Parafilaria bovicola in Burundi. Trop Anim Health Prod. 1985;17:1-2.

14. Metianu T. Considérations sur la parafilariose hémorragique des bovins. Parafilaria bovicola en Roumanie. Ann Parasitol Hum Comp. 1949;24:54-9.

15. Kretzmann PW, Wallace HG, Weaver DB. Manifestations of bovine parafilariasis. J S Afr Vet Assoc. 1984;55:127-9.

16. Pardon B, Zwaenepoel I, Vercauteren G, Claerebout E, Deprez P. Parafilariasis in a Belgian Blue breeding bull in Flanders. Vlaams Diergeneeskundig Tijdschrift. 2010;79:54-8.

17. Torgerson PRD, Michael L, Anne MH. Bovine haemorrhagic parafilariosis in an imported Charolais bull. Ir Vet J. 1998;51:27-9.

18. Bech-Nielsen S, Hugoson G, Wold-Troell M. Economic evaluation of several control programs for the cattle nematode Parafiliria bovicola using benefit-cost analysis. Prev Vet Med. 1983;1:303-20.

19. Stevanovic O, Babic R, Nedic D, Nikolic S, Dimitric R, Borkovic M, et al. First record of bovine parafilariosis in Bosnia and Herzegovina, western Balkans. Rev Med Vet. 2014;165:323-6.

20. Hofer J. Parafilaria bovicola beim Rind-eine neue auftretende Parasitose in Österreich. Klauentierpraxis. 2011;19:5-6.

21. Soulsby E. Textbook of veterinary clinical parasitology, vol. I. Helminths. 1st ed. Philadelphia: F.A. Davis Company; 1965.

22. Casiraghi M, Anderson T, Bandi C, Bazzocchi C, Genchi C. A phylogenetic analysis of filarial nematodes: comparison with the phylogeny of Wolbachia endosymbionts. Parasitology. 2001;122:93-103.

23. Gasser RB, LeGoff L, Petit G, Bain O. Rapid delineation of closely-related filarial parasites using genetic markers in spacer rDNA. Acta Trop. 1996:62:143-50.

24. Rademacher GF, Friedrich A, Majzoub M, Klee W. Krankheitssymptome und-verlauf bei einer Kuh mit Parafilariose. Tierärztliche Umschau. 2012;67:352-5
25. Stoll A, Pfitzner-Friedrich A, Reichmann F, Rauschendorfer J, Roessler A, Rademacher $\mathrm{G}$, et al. Existence of bovine neonatal pancytopenia before the year 2005? Retrospective evaluation of 215 cases of haemorrhagic diathesis in cattle. Vet J. 2016;216:59-63.

26. Friedrich ARG, Weber BK, Kappe E, Carlin A, Assad A, Sauter-Louis C, et al. Gehäuftes Auftreten von hämorrhagischer Diathese infolge Knochenmarksschädigung bei jungen Kälbern. Tierärztliche Umschau. 2009;64:423-31.

27. Friedrich A, Buttner M, Rademacher G, Klee W, Weber BK, Müller M, et al. Ingestion of colostrum from specific cows induces bovine neonatal pancytopenia (BNP) in some calves. BMC Vet Res. 2011;7:10.

28. Brooks DR, Hoberg EP. Systematics and emerging infectious diseases: from management to solution. J Parasitol. 2006;92:426-9.

29. van Dijk J, Sargison ND, Kenyon F, Skuce PJ. Climate change and infectious disease: helminthological challenges to farmed ruminants in temperate regions. Animal. 2010;4:377-92.

30. Kenyon F, Sargison ND, Skuce PJ, Jackson F. Sheep helminth parasitic disease in south eastern Scotland arising as a possible consequence of climate change. Vet Parasitol. 2009;163:293-7.

31. Kutz SJ, Jenkins EJ, Veitch AM, Ducrocq J, Polley L, Elkin B, et al. The Arctic as a model for anticipating, preventing, and mitigating climate change impacts on host-parasite interactions. Vet Parasitol. 2009;163:217-28.

32. Hoberg EP, Polley L, Jenkins EJ, Kutz SJ, Veitch AM, Elkin BT. Integrated approaches and empirical models for investigation of parasitic diseases in northern wildlife. Emerg Infect Dis. 2008;14:10-7.

33. Brooks DR, Hoberg EP. How will global climate change affect parasitehost assemblages? Trends Parasitol. 2007;23:571-4

34. Webster W, Wilkins D. The recovery of Parafilaria bovicola Tubangui, 1934 from an imported Charolais bull. Can Vet J. 1970;11:13-4.

35. Şaki CE, Sevgili M, Özer E. Parafilariosis in cattle in Malatya and environs. Turk J Vet Anim Sci. 1999;23:541-5.

36. Sundquist B, Zakrisson G, Bech-Nielsen S, Bianco AE. Preparation and evaluation of the specificity of Parafilaria bovicola antigen for detection of specific antibodies by ELISA. Vet Parasitol. 1988;28:223-35.

37. Sundquist B, Bech-Nielsen S, Zakrisson G. Characterization and purification of Parafilaria bovicola antigens by chromatofocusing to enhance specificity in serodiagnosis. Vet Parasitol. 1989;33:309-18.

38. Monte TC, Simões RO, Oliveira AP, Novaes CF, Thiengo SC, Silva AJ, et al. Phylogenetic relationship of the Brazilian isolates of the rat lungworm Angiostrongylus cantonensis (Nematoda: Metastrongylidae) employing mitochondrial COI gene sequence data. Parasit Vectors. 2012;5:248.

39. Hajibabaei M, Singer GA, Clare EL, Hebert PD. Design and applicability of DNA arrays and DNA barcodes in biodiversity monitoring. BMC Biol. 2007:5:24.

40. Hebert PD, Ratnasingham S, deWaard JR. Barcoding animal life: cytochrome c oxidase subunit 1 divergences among closely related species. Proc Biol Sci. 2003;270(Suppl. 1):96-9.

41. Sallum MAM, Schultz TR, Foster PG, Aronstein K, Wirtz RA, Wilkerson RC. Phylogeny of Anophelinae (Diptera: Culicidae) based on nuclear ribosomal and mitochondrial DNA sequences. Syst Entomol. 2002;27:361-82.

42. Clary DO, Wolstenholme DR. The mitochondrial DNA molecule of Drosophila yakuba: nucleotide sequence, gene organization, and genetic code. J Mol Evol. 1985;22:252-71.

43. Blouin MS. Molecular prospecting for cryptic species of nematodes: mitochondrial DNA versus internal transcribed spacer. Int J Parasitol. 2002:32:527-31.

44. Nevill EM, Wilkins CA, Zakrisson G. The control of Parafilaria bovicola transmission in South Africa. Onderstepoort J Vet Res. 1987;54:547-50.

45. Hokan M, Strube C, Radespiel U, Zimmermann E. Sleeping site ecology, but not sex, affect ecto- and hemoparasite risk, in sympatric, arboreal primates (Avahi occidentalis and Lepilemur edwardsi). Front Zool. 2017;14:44.

46. Nuchprayoon S, Junpee A, Poovorawan Y, Scott AL. Detection and differentiation of filarial parasites by universal primers and polymerase chain reaction-restriction fragment length polymorphism analysis. Am J Trop Med Hyg. 2005;73:895-900.

\section{Publisher's Note}

Springer Nature remains neutral with regard to jurisdictional claims in published maps and institutional affiliations. 